\title{
PENINGKATAN KEMAMPUAN BERCERITA MELALUI MEDIA KARTU SKENARIO DI SDN 08 VI SUKU, SOLOK
}

\section{IMPROVING THE STORYTELLING ABILITY OF ELEMENTARY SCHOOL O8 VI SUKU, SOLOK THROUGH SCENARIO CARDS}

\author{
Suri Amelia, Kastam Syamsi \\ SD Negeri 08 VI Suku Solok Sumatera Barat, Universitas Negeri Yogyakarta \\ ameliasuri@yahoo.co.id, kastam.syamsi@uny.ac.id
}

\begin{abstract}
Abstrak
Tujuan penelitian ini adalah mendeskripsikan: (1) proses peningkatan kemampuan bercerita dan peningkatan proses pembelajaran bercerita dengan menggunakan media kartu skenario, (2) hasil peningkatan kemampuan bercerita dan peningkatan proses pembelajaran bercerita dengan meng-gunakan media kartu skenario. Penelitian ini menggunakan desain penelitian tindakan kelas. Variabel penelitian meliputi variabel bebas berupa penggunaan media kartuskenario, dan variabel terikat berupa kemampuan belajar. Penelitian tindakan kelas ini diimplementasikan pada peserta didik kelas III di SD Negeri 08 VI Suku Solok karena diindikasikan bahwa kemampuan peserta didik dalam pembelajaran bercerita masih rendah. Penelitian dilaksanakan pada semester I tahun ajaran 2013/2014. Teknik pengumpulan data yang digunakan adalah berupa tes, observasi, catatan lapangan, dan dokumentasi. Hasil penelitian menunjukkan bahwa penggunaan media kartu skenario dalam pembelajaran bercerita terbukti berpengaruh terhadap peningkatan kemampuan dan proses pembelajaran bercerita siswa. Kemampuan bercerita peserta didik mengalami peningkatan, yaitu dari rata-rata 70,86 pada siklus 1 menjadi 80,00 pada siklus 2 dengan klasifikasi baik. Ketuntasan belajar klasikal dari $40 \%$ di siklus 1 meningkat menjadi $77 \%$ di siklus 2. Aktivitas guru dalam proses pembelajaran menunjukkan rata-rata 75,00 diklasifikasikan baik pada siklus 1 menjadi 86,00 pada siklus 2 dengan klasifikasi sangat baik. Aktivitas siswa dalam proses pembelajaran dari rata-rata 72,07 pada siklus 1 menjadi 82,93 pada siklus 2 dengan klasifikasi sangat baik. Jadi pelaksanaan tindakan menggunakan media kartu skenario telah mencapai indikator keberhasilan dalam penelitian ini, yakni nilai perolehan rata-rata kemampuan bercerita $\geq 75,00$ dan ketuntasan belajar klassikal mencapai $75 \%$. Pelaksanaan proses pembelajaran baik dari aktivitas guru maupun aktivitas siswa memperoleh rata-rata $>80,00$ dengan klasifikasi sangat baik. Dengan demikian penggunaan media kartu skenario dapat meningkatkan kemampuan bercerita dan dapat meningkatkan proses pembelajaran bercerita siswa kelas III di SD Negeri 08 VI Suku, Solok.
\end{abstract}

Kata Kunci: kemampuan bercerita, media kartu skenario

\section{Abstract}

This study aims to describe: (1) the process of improving the students' storytelling ability and learning process by using scenario cards, (2) the result of improving the students' storytelling ability and learning process by using scenario cards. This study used the action research design. The variables of the research included an independent variable in the form of the use of scenario cards and a dependent variable in the form of storytelling abilities. This research was implemented to the students of Class III, SDN 08 VI Suku since it was indicated that the storytelling ability and the learning process in storytelling were still low. This research was conducted in the first semester of the school year of 2013/2014. The data collection techniques used were atest, observation, field notes, and documentation. The study revealed that the use of scenario cards in the teaching and learning process of storytelling improves the students' storytelling abilities and learning process. The students' storytelling abilities have improved from the overall mean of 70.86 in the first cycle to 80.00 in the second cycle, that is from good into very good. The mean of the teachers' activity in the learning process was 75.00 and classified good in the first cycle changed to 86.00 in the second cycle and classified very good. The mean of the students' activity in the teaching process was 72.07 and classified good in the first cycle changed to 82.93 in the second cycle and classified very good. In short, the use of scenario cards was successful in this study, that is the mean of students' storytelling abilities $\geq 75$ and classical mastery learning $75 \%$. The mean of the learning process from either teacher's activities or students' activities was $>80.00$ and classified very good. Thereby, the use of scenario cards can improve the students' storytelling ability and teaching process in Class III SDN 08 VI Suku, Solok.

Keywords: storytelling abilities, scenario cards media 


\section{Pendahuluan}

Salah satu aspek penting dalam keterampilan berbahasa adalah berbicara. Berbicara merupakan kemampuan berbahasa yang bersifat aktif produktif yang menuntut kegiatan encoding, yakni kegiatan menghasilkan bahasa kepada pihak lain secara lisan (Nurgiyantoro, 2012, p.397). Selain itu berbicara berperan dalam melahirkan generasi masa depan yang cerdas, kritis, kreatif, dan berbudaya. Linguis mengatakan "speaking is language". Berbicara adalah suatu keterampilan berbahasa yang berkembang pada kehidupan anak (Tarigan, 2008, p.3). Anak-anak sudah mengenal bahasa jauh sebelum mereka memasuki usia sekolah, terutama pada menyimak dan berbicara.

Menurut Heath (dalam Tompkins \& Hoskisson, 1995, p.120), berbicara pada siswa di sekolah dasar merupakan bagian dari seni berbahasa yang sangat esensial dan diperlukan untuk keberhasilan dalam semua bidang akademis. Terampilnya siswa berbicara juga akan berdampak terhadap bidang akademis lainnya. Berbicara sebagai bahasa lisan sangat penting bagi semua siswa di semua tingkat sekolah dan dapat mempengaruhi kemampuan mereka dalam menulis (Donoghue, 2009, p.371).

Salah satu bentuk komunikasi lisan yang dapat digunakan untuk meningkatkan kemampuan berbicara yang bersifat pragmatis adalah bercerita. Bercerita merupakan salah satu kebiasaan masyarakat sejak dahulu sampai sekarang yang sangat berpengaruh terhadap jiwa manusia, dan sangat efektif untuk mempengaruhi jiwa anak-anak. Bercerita sebagai suatu kebiasaan telah banyak digunakan dalam mengajar, menghibur, dan untuk menjelaskan hal-hal yang tidak diketahui (Richard-Amato, 2003, p.215). Pada umumnya, manusia senang melakukan kegiatan bercerita dari usia anakanak sampai dewasa.

Bercerita dapat dipahami sebagai suatu tuturan yang memaparkan/menjelaskan bagaimana terjadinya suatu hal, peristiwa, dan kejadian, baik yang dialami sendiri maupun orang lain. Seseorang dapat bertukar pengalaman, perasaan, informasi dan keinginannya melalui kegiatan bercerita. Bercerita juga melibatkan pikiran, kesiapan mental, keberanian, perkataan yang jelas sehingga mudah dipahami oleh orang lain. Melalui kegiatan bercerita anak-anak dapat mengembangkan daya imajinasi dan memperluas minatnya, anak belajar mengenal manusia dan kehidupan, serta dirinya sendiri, meluaskan dunia dan pengalaman hidupnya (Bunanta, 2008, p.22). Di samping itu, kegiatan bercerita dapat membangun hubungan mental, emosional antara satu individu dengan individu lain.

Pada pembelajaran di Sekolah Dasar (SD), bercerita bukanlah suatu kegiatan yang asing bagi siswa. Mengacu pada standar kompetensi dan kompetensi dasar pelajaran bahasa Indonesia yang ada pada standar isi (Depdiknas, 2006, pp.121-132), kegiatan bercerita sudah mulai diberikan pada siswa kelas rendah yakni kelas I dan II yang berfokus pada bercerita bebas mengenai diri sendiri. Namun, pada tingkat yang lebih tinggi seperti kelas III-VI kegiatan bercerita lebih banyak dilakukan melalui kegiatan membaca. Siswa ditugaskan bercerita setelah melakukan kegiatan membaca.

Berbeda dengan aspek keterampilan bahasa lainnya, aspek bercerita tergolong sulit bagi siswa, terutama di kelas III. Hal ini dapat dilihat pada hasil rata-rata ulangan harian pada semester I tahun ajaran 2013/2014 dalam aspek berbicara (bercerita) adalah 68,00. Nilai ratarata ini masih belum mencapai Kriteria Ketuntasan Mininal (KKM) yang ditetapkan oleh guru kelas untuk pelajaran bahasa Indonesia, yakni 75,00 .

Berdasarkan observasi dan wawancara peneliti dengan guru dan beberapa siswa kelas III SD Negeri 08 VI Suku Solok pada hari Rabu, 09 Oktober 2013, terungkap bahwa rendahnya kemampuan bercerita siswa disebabkan karena kurangnya siswa melakukan kegiatan membaca. Ketika guru memberikan tugas membaca cerita, sebagian besar siswa tidak membaca. Permasalahan yang dihadapi dalam pembelajaran bercerita yang terkait dengan kemampuan bercerita dan proses pembelajaran bercerita adalah (1) siswa kurang berkonsentrasi, kurangnya minat dan perhatian dalam pembelajaran berbicara khusunya bercerita, (2) siswa tampak malas melakukan kegiatan membaca, hal ini terlihat mereka hanya membolak-balik buku saja tanpa melakukan kegiatan membaca dengan serius dan sungguh-sungguh, (3) dalam pembelajaran bercerita guru menggunakan metode ceramah dan penugasan, (4) guru belum pernah menggunakan metode diskusi kelompok karena pembelajaran secara individual lebih mudah dilaksanakan, (5) dalam pembelajaran bercerita guru belum pernah menggunakan media apapun, (6) nilai KKM yang ditetapkan untuk pembelajaran bercerita adalah 75,00, (7) pada akhir pertemuan, yang dilaksanakan pada hari Rabu, tanggal 9 Oktober 2013, guru mela- 
kukan tes praktik terhadap kemampuan siswa dalam bercerita dengan bahasa dan gaya yang sesuai. Dari hasil tes yang diperoleh presentase siswa yang mendapat nilai $\geq \mathrm{KKM}$ adalah $23 \%$ atau sebanyak 8 orang, $77 \%$ atau sebanyak 27 orang belum tuntas atau berada di bawah KKM, dengan perolehan nilai rata-rata adalah 68,00 , (8) menurut guru kelas, terdapat faktor yang mempengaruhi kurang berhasilnya pembelajaran bercerita, misalnya sulit mendapat media pembelajaran yang cocok, sikap atau respon siswa yang kurang menyukai pembelajaran bercerita, siswa sangat kesulitan memahami alur cerita yang ada pada teks cerita, sulit mengganti pilihan kata dalam cerita, gugup dan takut salah, malu menampilkan ekspresi dalam bercerita, dan lain-lain dan (9) menurut guru kelas, hal-hal yang kemungkinan besar mempengaruhi keberhasilan proses pembelajaran bercerita adalah penggunaan suatu media pembelajaran yang dapat membantu dan mengarahkan pola pikir siswa untuk memahami cerita, serta metode pembelajaran yang harus lebih melibatkan siswa agar lebih aktif, karena dari fakta yang ada di lapangan, saat pembelajaran berlangsung siswa terlalu pasif dan tidak berani untuk bertanya atau mengungkapkan gagasan.

Berdasarkan identifikasi permasalahan dari hasil observasi kondisi awal, selanjutnya disimpulkan bahwa masalah besar yang terjadi dalam pembelajaran tersebut adalah belum adanya penggunaan media pembelajaran yang tepat dan menarik perhatian, minat, dan aktivitas siswa serta proses pembelajaran yang belum optimal di kelas yang sekaligus dapat mempengaruhi kemampuan bercerita siswa. Dengan demikian, penggunaan media pembelajaran perlu mendapatkan penanganan sebagai upaya pemecahan masalah dengan memberikan tindakan dalam proses pembelajaran.

Untuk mengatasi hal yang demikian seyogyanya guru mencari solusi yang tepat dalam memperbaiki pembelajaran di kelasnya. Salah satu solusi yang dipilih guru untuk meningkatkan kemampuan bercerita adalah menggunakan media berupa kartu yang dinamakan media kartu skenario.

Media kartu skenario ini terdiri dari kartu-kartu kecil dengan ukuran 8.5 × $6 \mathrm{~cm}$ yang berisi skenario atau penggalan cerita dan kartu gambar cerita. Penggunaan media kartu skenario dalam pembelajaran bercerita, terutama dalam kelompok besar maupun kecil menjadikan siswa aktif, dan dapat berinteraksi dengan teman sebaya, serta berusaha untuk menguasai cerita sebaik mungkin. Hal ini sesuai dengan aliran teori belajar konstruktivis. Menurut Geary (dalam Schunk, 2008, p.237), asumsi utama dalam konstruktivis, manusia merupakan siswa aktif yang mengembangkan pengetahuan bagi diri mereka sendiri. Untuk itu, dalam proses pembelajaran sebaiknya guru tidak hanya mengajar dalam artian menyampaikan pelajaran secara tradisional. Guru seharusnya membangun situasi-situasi sedemikian rupa sehingga siswa terlibat secara aktif dengan materi pembelajaran melalui pengolahan materi-materi dan interaksi sosial. Salah satu bentuk situasi yang dapat dibentuk oleh guru dalam pembelajaran adalah dengan menggunakan media kartu skenario.

Menurut Nur (dalam Trianto, 2007, p.13) dalam teori konstruktivis, satu prinsip yang paling penting dalam psikologi pendidikan adalah bahwa guru tidak hanya sekedar memberikan pengetahuan kepada siswa. Siswa harus membangun sendiri pengetahuan di dalam benaknya. Guru dapat memberikan kemudahan untuk proses ini, dengan memberikan kesempatan kepada siswa untuk menemukan atau menerapkan ide-ide mereka sendiri, dan mengajar siswa menjadi sadar dan secara sadar menggunakan strategi mereka sendiri untuk belajar. Guru dapat memberi siswa anak tangga yang membawa siswa ke pemahaman yang lebih tinggi, dengan catatan siswa sendiri yang harus memanjat anak tangga tersebut.

Media kartu skenario merupakan salah satu bentuk dari media kartu (flashcard). Flashcard adalah salah satu bentuk media pembelajaran dalam bentuk kartu bergambar dengan ukuran bermacam-macam sesuai dengan kebutuhan. Flashcard banyak digunakan dalam berbagai mata pelajaran, karena memiliki berbagai manfaat. Menurut Blair (2013, p.1) flashcard merupakan alat yang ampuh untuk membantu mengingat informasi seperti makna kosakata, rumus matematika, fakta sejarah, dan ejaan yang benar dari kata-kata, dan sebagainya. Selain itu mudah dibawa, praktis, gampang diingat, dan menyenangkan (Nurseto, 2011, p.27). Penggunaan media kartu skenario memudahkan guru untuk menyampaikan materi pembelajaran, menghidupkan suasana pembelajaran, menimbulkan minat siswa, menjadikan siswa aktif, dan memudahkan guru untuk mencapai tujuan pembelajaran.

Kartu skenario sengaja dipilih karena sebelumnya guru tidak pernah menggunakan media dalam pembelajaran bercerita. Siswa 
disajikan cerita yang terdapat dalam buku paket yang ada di kelas. Di samping itu, pemilihan kartu skenario selain bermanfaat bagi guru, juga sangat bermanfaat bagi siswa. Siswa dapat memahami cerita dengan mudah, tidak jenuh melakukan kegiatan membaca karena wacana atau cerita dipenggal dalam beberapa kartu dengan kalimat yang singkat dan mudah dipahami, dan diikuti oleh urutan gambar dari cerita yang disajikan. Gambar berfungsi untuk membantu siswa untuk mengingat urut-urutan cerita. Selain itu, gambar juga dapat membantu siswa dalam meniru ekspresi tokoh yang ada dalam cerita. Dengan adanya gambar, siswa tidak merasa mereka sudah banyak membaca cerita atau wacana sehingga kemampuan membaca mereka juga dapat ditingkatkan. Kartu skenario merupakan salah satu media yang efektif untuk meningkatkan partisipasi aktif siswa, menimbulkan suasana pembelajaran yang menyenangkan dan diharapkan juga mampu meningkatkan kemampuan bercerita siswa kelas III SD Negeri 08 VI Suku Solok. Berpijak pada beberapa hal di atas, peneliti terdorong untuk ikut menyumbangkan pemikiran dalam bentuk penelitian. Secara garis besar penelitian ini membahas mengenai peningkatan kemampuan bercerita melalui media kartu skenario pada siswa kelas III SD Negeri 08 VI Suku Solok.

\section{Metode Penelitian}

\section{Jenis Penelitian}

Jenis penelitian yang dilakukan adalah Penelitian Tindakan Kelas (Classroom Action Research).Desain dalam penelitian ini menggunakan jenis penelitian tindakan kelas model Kemmis \& Taggart (1990, p.22). Penelitian tindakan kelas ini mempunyai 3 kegiatan untuk tiap siklusnya yaitu: (1) perencanaan, (2) pelaksanaan dan observasi, dan (3) refleksi.

Waktu dan Tempat Penelitian

Penelitian ini dilakukan di SD Negeri 08 VI Suku Kota Solok Jalan. Tandikat Kelurahan VI Suku, Kecamatan Tanjung Harapan, Kota Solok, Provinsi Sumatera Barat. Penelitian ini mulai dilaksanakan pada bulan Oktober sampai bulan November 2013 pada semester I tahun ajaran 2013/2014.

\section{Subjek Penelitian}

Subjek dalam penelitian ini adalah siswa kelas III SD Negeri 08 VI Suku Solok pada tahun ajaran 2013/2014. Jumlah siswa yang diteliti sebanyak 35 orang, yang terdiri dari 15 orang siswa siswa laki-laki dan 20 orang siswa perempuan.

\section{Data, Teknik Pengumpulan Data dan Teknik} Analisis Data

Teknik pengumpulan data pada penelitian ini adalah dengan tes praktik bercerita, observasi/pengamatan, catatan lapangan dan dokumentasi. Instrumen utama atau instrumen kunci dari penelitian ini adalah kehadiran peneliti di ruang kelas. Di samping itu, terdapat beberapa instrumen lain yang digunakan dalam penelitian ini yaitu soal tes/tes unjuk kerja, lembar observasi, catatan lapangan dan dokumentasi kegiatan.

Jenis data yang terdapat dalam penelitian ini yakni data kuantitatif dan data kualitatif, maka teknik analisis data yang digunakan adalah statistik deskriptif. Analisis data secara deskriptif digunakan untuk mendeskripsikan data penelitian apa adanya dan tidak digunakan untuk mengambil kesimpulan statisik.

Data kualitatif dalam penelitian ini adalah proses pembelajaran yang mencakup aktivitas guru dan aktivitas siswa dalam pembelajaran bercerita, catatan lapangan, dan dokumentasi. Prosedur ini dilakukan untuk menganalisis data kualitatif untuk mendapatkan gambaran utuh dari hasil penelitian setelah ditelaah secara kuantitatif.

Salah satu karakteristik analisis data dalam penelitian kualitatif adalah adanya proses pengumpulan data dan verifikasi data yang berkelanjutan (Hopkins, 2011, p.236). Adapun prosedur analisis data kualitatif menurut Miles dan Huberman (Hopkins, 2011, p.237) bersifat interaktif yang meliputi: kegiatan reduksi data, tampilan data/display, dan penarikan kesimpulan/verifikasi.

\section{Hasil Penelitian dan Pembahasan}

\section{Siklus I}

Deskripsi proses pelaksanaan tindakan dalam siklus 1 adalah sebagai berikut.

\section{Penggunaan Media Kartu Skenario}

Media kartu skenario yang digunakan dalam pembelajaran bercerita sudah cukup baik dalam meningkatkan proses pembelajaran dan kemampuan bercerita siswa, meski peningkatan yang terjadi belum sesuai dengan yang diharapkan. Media kartu skenario yang dirancang oleh guru terdiri dari 14 pasang kartu gambar dan kartu skenario (penggalan cerita) Timun Mas. Kartu yang berukuran $8.5 \times 6$ centimeter ini 
dibuat melalui proses laminating, sehingga awet dan dapat digunakan dalam jangka waktu yang lama. Kartu gambar tersebut telah diberi nomor urut sesuai dengan cerita, sementara kartu skenario (penggalan cerita) tidak diberi nomor urut (masih acak). Tugas siswa disini mencocokkan kartu gambar dengan kartu skenario, sehingga menjadi cerita yang urut. Dalam mencocokkan kartu skenario dan kartu gambar siswa membutuhkan waktu yang cukup lama.

Dalam tahap awal, 14 pasang kartu ini digunakan di dalam kelompok besar (12 orang). Diharapkan setiap siswa mendapat satu pasang kartu. Ketidaksesuaian jumlah kartu dengan jumlah anggota kelompok menimbulkan beberapa kendala. Beberapa siswa ada yang mendominasi kartu, sehingga teman lain kurang kesempatan untuk menggunakan kartu dengan leluasa. Kelas menjadi sedikit ricuh, dimana siswa tidak mau mendapat kartu lebih dari satu pasang. Selain itu, siswa berebut memilih kartu skenario yang ceritanya singkat, dan mengabaikan skenario cerita yang agak panjang. Siswa yang mendapat kartu skenario yang agak panjang membutuhkan waktu yang lama untuk dapat menguasai cerita.

\section{Aktivitas Guru dalam Proses Pembelajaran}

Pada pertemuan pertama, proses pembelajaran menyangkut aktivitas guru sudah mengalami peningkatan dari sebelum adanya tindakan. Aktivitas guru dalam pembelajaran menyangkut tiga hal pokok, yaitu kegiatan awal, kegiatan inti dan kegiatan akhir atau penutup. Guru melaksanakan pembelajaran sudah mengikuti langkah-langkah yang terdapat di dalam Rencana Pelaksanaan Pembelajaran (RPP), namun, masih perlu ditingkatkan lagi.

Kegiatan awal pada pertemuan pertama yang menyangkut apersepsi dilakukan oleh guru dengan cukup baik. Penayangan video kegiatan bercerita yang dibawakan oleh nominasi nasional mampu memancing perhatian dan minat siswa. Semua siswa dengan serius memperhatikan penayangan tersebut. Siswa kelihatan antusias dan gembira.

Pada kegiatan inti pembelajaran, aktivitas guru juga sudah cukup baik. Penggunaan media pembelajaran diawali dengan teks cerita "Timun Mas" sudah dapat menimbulkan rasa ingin tahu siswa. Semua siswa kelihatan aktif dan konsentrasi membaca cerita, bahkan ada di antara mereka yang berdiskusi tentang cerita yang sedang mereka baca. Guru memberikan kesempatan kepada siswa untuk bertanya jawab mengenai cerita, hal-hal yang menarik dan menyedihkan dari cerita, unsur-unsur cerita, membahas kata-kata sulit yang ada dalam cerita, dan meminta siswa untuk memberikan tanggapannya terhadap cerita. Guru sudah melibatkan siswa secara aktif di dalam pembelajaran.

Bagian akhir kegiatan pembelajaran (penutup) guru memberikan catatan singkat kepada siswa mengenai unsur-unsur cerita. Kegiatan pembelajaran pada pertemuan pertama ini terkesan agak tergesa-gesa karena guru khawatir waktu yang digunakan tidak sesuai dengan yang telah direncanakan sebelumnya.

Pemberian tindakan dilaksanakan pada pertemuan kedua. Guru sudah menyiapkan media pembelajaran berupa kartu yakni media kartu skenario. Guru memperkenalkan kepada siswa media kartu skenario yang digunakan pada pembelajaran kali ini, penggunaannya, dan manfaatnya bagi siswa.

Pada tahap awal, penggunaan media kartu skenario ini dilakukan dalam kelompok besar. Guru membagi siswa atas 3 kelompok, dimana satu kelompok beranggotakan 12 orang, setiap kelompok mendapatkan 14 pasang kartu. Pembagian kelompok besar ini dilakukan karena jumlah kartu skenario cerita yang telah dirancang. Diharapkan setiap siswa mendapatkan satu pasang kartu untuk mereka kuasai. Karena jumlah kartu 14 pasang, sementara jumlah siswa dalam kelompok ada 12 orang, maka terdapat dua orang siswa yang mendapatkan kartu 2 pasang.

Pada kegiatan ini, guru agak kesulitan dalam pengelolaan kelompok belajar, dimana jumlah anggota kelompok yang terlalu besar menjadikan kelas ramai dan siswa berebut meminta perhatian guru. Bahkan, salah satu kelompok kurang dapat bekerja sama dengan sesama anggota kelompoknya. Siswa yang pintar mendominasi penyusunan media kartu skenario dan tidak memberikan kesempatan pada siswa lainnya. Siswa yang tidak berkesempatan menggunakan kartu menjadi kesal dan terjadi kegaduhan kecil.

Siswa ditugaskan oleh guru untuk berlatih dan bekerjasama di dalam kelompoknya masing-masing, karena di akhir kegiatan siswa harus menampilkan cerita secara kelompok. Siswa sangat antusias berlatih di dalam kelompoknya, guru berkeliling memantau diskusi kelompok, sesekali guru memberikan bantuan terhadap kelompok yang mengalami kesulitan. Dalam pelaksanaan proses pembelajaran ini guru tidak terfokus pada satu strategi mengajar, 
selain di dalam kelompok guru juga meminta siswa di bangku masing-masing untuk berdiri membacakan bagian cerita yang didapat di dalam kelompoknya. Kegiatan ini dilakukan bertujuan untuk mengurangi kejenuhan siswa dan siswa lain juga dapat berbagi ekspresi dengan teman dari kelompok lainnya. Selain bercerita di tempat duduk masing-masing, guru juga memilih beberapa siswa yang bercerita secara kelompok yang merupakan wakil dari tiap-tiap kelompok.

Pada akhir kegiatan inti, guru memberikan kesempatan pada tiap-tiap kelompok untuk menampilkan cerita secara utuh. Pada kegiatan ini guru juga agak kesulitan dalam pengelolaan kelas, dimana banyaknya anggota kelompok yang tampil ke muka kelas menimbulkan suasana gaduh, sehingga waktu tersita untuk menertibkan siswa. Alhasil, tidak semua kelompok bisa menampilkan cerita, hanya satu kelompok saja. Kelompok lain yang tidak tampil diminta untuk memberikan tanggapannya. Bagi kelompok lain yang belum tampil diminta mempersiapkan diri pada pembelajaran berikutnya. Selanjutnya guru menutup pelajaran. Aktivitas guru pada pertemuan kedua ini sudah mulai mengalami peningkatan dari pada pertemuan sebelumnya.

Pada pertemuan ketiga dalam siklus 1 ini, pembelajaran dibuka oleh guru dengan menampilkan kegiatan bercerita secara berkelompok oleh kelompok yang belum tampil pada hari sebelumnya. Selanjutnya guru melakukan tes penilaian praktik bercerita secara individu. Pelaksanaan tes praktik bercerita berjalan cukup alot, karena masih banyak siswa yang belum menguasai cerita. Waktu yang dibutuhkan untuk mengevaluasi terhadap masing-masing siswa yang berjumlah 35 orang tidak cukup dalam 3 jam pelajaran, sehingga kegiatan evaluasi dilanjutkan diluar jam pelajaran. Hari yang dipilih adalah hari Sabtu, dalam jam pengembangan diri.

Berdasarkan deskripsi tersebut, secara umum aktivitas guru dalam proses pembelajaran pada siklus 1 yang diamati dalam dua kali pertemuan ini sudah cukup baik, baik dari kegiatan awal, kegiatan inti, maupun dalam kegiatan akhir (penutup). Perolehan skor rata-rata aktivitas guru adalah 75,00 dengan kategori baik. Perolehan skor ini belum sesuai dengan harapan. Aktivitas guru dalam proses pembelajaran diharapkan mencapai skor rata-rata $\geq 80,00$ dengan kategori sangat baik, jadi perlu ditingkatkan lagi pada siklus berikutnya.

\section{Aktivitas Siswa dalam Proses Pembelajaran}

Aktivitas siswa pada proses pembelajaran bercerita yang diamati adalah keaktifan, perhatian dan konsentrasi, minat, dan keberanian. Peningkatan aktivitas siswa dalam proses pembelajaran bercerita sudah tampak pada awal pertemuan pertama. Meskipun peningkatan yang terjadi masih sedikit. Perhatian dan minat siswa dalam pembelajaran bercerita sudah cukup baik. Penayangan video bercerita pada awal pembelajaran sudah mampu menarik minat dan perhatian siswa pada kegiatan bercerita. Siswa aktif membicarakan dan menanggapi cerita dalam tayangan video yang ditampilkan oleh guru.

Pada pertemuan selanjutnya, dengan adanya media kartu skenario yang digunakan, aktivitas siswa semakin meningkat. Terutama pada aspek keaktifan. Hampir semua siswa ikut terlibat aktif dalam penggunaan kartu, pembelajaran terlihat menarik dan menyenangkan. Mereka tampak aktif bekerja sama dalam kelompok. Sebelumnya, mereka belum pernah membentuk kelompok dan belum pernah menggunakan kartu cerita dalam pembelajaran bercerita. Siswa sibuk membaca kartu skenario untuk dicocokkan dengan gambar. Meskipun agak sedikit gaduh dan ramai, tetapi siswa merasa senang dan tidak jenuh. Siswa memiliki perhatian dan konsentrasi ketika menyusun kartu-kartu gambar dan kartu skenario cerita. Aktivitas siswa pada pada aspek keberanian, masih terlihat masih kurang. Siswa masih malumalu untuk mengungkapkan ekspresi, malu menggunakan intonasi, dan masih belum berani untuk tampil bercerita secara spontan.

Secara umum rata-rata aktivitas siswa dalam proses pembelajaran sudah berada pada kategori baik, yakni 72,07. Secara individu, terdapat sebanyak 13 orang siswa yang memperoleh rata-rata dengan kategori cukup (nilai ratarata aktivitas berada pada rentang $>40-60$ ). Hal ini perlu ditingkatkan lagi sehingga $75 \%$ siswa memperoleh rata-rata sangat baik dan nilai rata-rata aktivitas siswa berada pada kategori sangat baik dengan skor rata-rata $\geq$ 80,00 .

\section{Kemampuan Bercerita Siswa}

Penilaian kemampuan bercerita siswa dilaksanakan pada akhir siklus. Pelaksanaan tes praktik bercerita tidak berdasarkan nomor urut absen, tetapi penampilan siswa diundi dengan nomor urut absen. Guru membuat nomor $1-35$ 
pada kertas tertutup, siswa lain mengambil nomor dan membacakan nomor yang diambil. Cara ini dianggap cara yang paling tepat agar semua siswa dapat mempersiapkan diri dalam menampilkan kemampuan mereka. Cara ini juga tidak menimbulkan kegaduhan.

Kemampuan bercerita siswa meliputi 6 (enam) aspek yang dinilai, yakni (1) ketepatan isi cerita, (2) ketepatan pilihan kata/diksi, (3) kejelasan lafal dan intonasi suara, (4) ketepatan makna seluruh cerita, (5) ketepatan ekspresi, dan (6) kelancaran bercerita. Kemampuan bercerita siswa pada siklus 1 ini baru menunjukkan sedikit peningkatan dari sebelum menggunakan tindakan. Beberapa siswa (lima orang) sudah mampu bercerita dengan sangat baik. Hal ini dapat dilihat dari perolehan skor rata-rata yang mereka peroleh berada $\geq 80,00$. Mereka sudah mampu memahami cerita dan mampu menguasai alur cerita, menguasai tokoh-tokohnya dan memahami unsur-unsur cerita, sehingga siswa dapat bercerita sesuai dengan isi cerita yang telah mereka baca. Mereka juga sudah dapat menggunakan ekspresi, menggunakan lafal dan intonasi suara yang baik.

Sebagian besar siswa mampu bercerita dengan baik namun masih perlu peningkatan untuk mencapai ketuntasan yang telah ditetapkan. Beberapa diantaranya masih kelihatan malu dan grogi ketika bercerita, kurang lancar dan terbata-bata, bahkan ada yang bercerita seperti membaca, tanpa ekspresi dan terlihat kaku. Beberapa siswa ada yang bercerita hanya untuk dirinya sendiri dengan suara yang sangat pelan atau berbisik. Banyak diantara siswa yang masih kurang mampu dalam memilih kata/diksi ketika bercerita. Mereka cenderung menggunakan kata yang persis sama dengan kata yang ada dalam cerita, sehingga banyak jeda, dan waktu untuk bercerita menjadi tersita.

Perolehan skor rata-rata kemampuan bercerita siswa berada pada kategori baik, yakni 70,86. Hal ini belum sesuai dengan indikator keberhasilan yang telah ditetapkan dalam penelitian ini, yaitu 75,00. Secara individual masih banyak siswa yang belum mencapai ketuntasan, yakni sebanyak 22 siswa atau sebesar $40 \%$, diharapkan $75 \%$ siswa tuntas dalam bercerita.

Beberapa aspek penilaian kemampuan bercerita seperti ketepatan isi cerita dan ketepatan makna seluruh cerita sudah sangat baik, aspek lafal dan intonasi suara dan kelancaran bercerita sudah baik, namun masih perlu ditingkatkan. Aspek kemampuan bercerita yang sangat perlu mendapat perhatian dan peningkatan adalah aspek pilihan kata/diksi dan aspek ketepatan ekspresi yang berada pada kategori cukup, dengan perolehan rata-rata 58,00. Diharapkan seluruh aspek kemampuan bercerita meningkat dan berada pada kategori baik (>6080).

\section{Manajemen Kelas}

Manajemen kelas dalam pembelajaran bercerita menggunakan kartu skenario ini menyangkut alokasi waktu, variasi kegiatan belajar, dan penanganan terhadap siswa yang pasif dan tidak memiliki keberanian dalam bercerita. Manajemen kelas pada siklus 1 ini perlu untuk ditingkatkan lagi. Guru masih belum dapat mengelola waktu pembelajaran dengan baik. Banyak waktu dihabiskan untuk menertibkan siswa, mengatur tempat duduk, menampilkan kegiatan bercerita dan sebagainya. Variasi yang dilakukan guru dalam proses pembelajaran sudah baik, siswa tidak hanya belajar secara individual, namun sudah dibentuk kelompok besar, maupun kecil, meskipun selalu ada kendala. Guru masih belum dapat memotivasi beberapa siswa yang bersikap pasif, dan tidak mau tampil dalam bercerita. Untuk ini, guru perlu mencari solusi yang tepat agar siswa yang bermasalah dapat ditangani, sehingga mereka dapat mengikuti teman-teman yang lainnya.

Berdasarkan hasil pengamatan, capaian keberhasilan pada siklus 1 adalah sebagai berikut.

Pertama, Penggunaan media kartu skenario dalam pembelajaran bercerita sudah cukup berhasil memperbaiki proses pembelajaran, baik dari segi aktivitas guru, maupun aktivitas siswa, meskipun peningkatan yang terjadi baru sedikit dan belum sesuai dengan yang diharapkan. Penggunaan kartu skenario kurang efektif jika digunakan pada kelompok siswa yang terlalu banyak. Siswa kurang memiliki waktu yang penuh untuk dapat memahami dan menghafal cerita, karena berebut dengan teman lainnya.

Kedua, Aktivitas guru dalam proses pembelajaran sudah dapat dikatakan cukup ada perubahan ke arah yang lebih baik. Namun, perlu ditingkatkan lagi seoptimal mungkin, memperbaiki segala kelemahan dan kekurangan yang dilakukan pada pembelajaran sebelumnya, sehingga proses pembelajaran yang dilakukan oleh guru menjadi sangat baik.

Ketiga, Aktivitas siswa dalam proses pembelajaran sudah mengalami peningkatan 
yang cukup baik. keterlibatan siswa dalam pembelajaran seperti keaktifan, perhatian dan konsentrasi, minat, sudah mulai menampakkan hasil yang baik, namun pada aspek keberanian masih sangat perlu ditingkatkan lagi. Secara keseluruhan, aktivitas siswa dalam pembelajaran bercerita belum mencapai hasil yang maksimal, sehingga perlu ditingkatkan lagi menjadi sangat baik.

Keempat, Kemampuan bercerita siswa baru ada sedikit peningkatan. Peningkatan yang terjadi kemungkinan besar disebabkan karena siswa kurang memiliki waktu yang cukup untuk berlatih di dalam kelompok, kurang leluasa menggunakan media kartu skenario. Untuk itu, perlu ditingkatkan lagi pada siklus berikutnya agar kemampuan bercerita siswa dapat meningkat sesuai dengan yang diharapkan.

Kelima, Manajemen kelas dapat dikatakan kurang berhasil. Waktu yang digunakan dalam pembelajaran yang belum maksimal perlu diperbaiki oleh guru demi tercapainya tujuan pembelajaran, guru juga harus dapat menggunakan variasi ketika mengajar, dan menemukan cara yang jitu untuk dapat memotivasi siswa yang pemalu agar berani tampil bercerita dengan percaya diri di muka kelas.

Siklus II

Deskripsi selengkapnya untuk pelaksanaan tindakan siklus 2 ini akan disampaikan sebagai berikut.

\section{Penggunaan Media Kartu Skenario}

Pada siklus 2 ini, penggunaan media kartu skenario sudah lebih efektif dari pada siklus sebelumnya. Guru memperbanyak jumlah kartu yakni sebanyak 7 set kartu untuk 7 kelompok. Pada pertemuan pertama kartu skenario tetap digunakan di dalam kelompok, namun kelompok kecil, yang terdiri dari 5 orang. Kartu skenario cerita Timun Mas jumlahnya tetap 14 pasang. Pada pertemuan kedua, kartu skenario cerita Timun Mas digunakan pada kelompok kecil (2 orang) dengan teman sebangku. Siswa mendapatkan 14 pasang kartu gambar-skenario. Penggunaan kartu skenario semakin baik, dimana siswa mendapatkan kesempatan untuk memahami jalan cerita tanpa harus berebut dengan teman-teman lainnya.

\section{Aktivitas Guru dalam Proses Pembelajaran}

Sebagaimana pada siklus 1, pada siklus 2 ini, aktivitas guru dalam pembelajaran menyangkut tiga hal pkok, yaitu kegiatan awal, kegiatan inti, dan kegiatan akhir (penutup). Aktivitas guru pada kegiatan awal dalam pertemuan pertama sudah sangat baik. guru sudah sangat baik dalam mempersiapkan siswa untuk mengikuti pembelajaran. Penayangan video kegiatan bercerita melalui in fokus tetap dilakukan oleh guru dengan tujuan agar peserta didik lebih termotivasi lagi melakukan kegiatan bercerita, memiliki minat dan perhatian yang tinggi dalam kegiatan bercerita, dan memiliki keberanian untuk berekspresi di depan kelas dan dihadapan teman-temannya. Judul cerita dalam penayangan video berbeda dengan cerita yang ditayangkan pada siklus 1 . Siswa menyaksikan tayangan tersebut dengan konsentrasi. Pada akhir kegiatan awal, siswa dan guru bertanya jawab mengenai tayangan video yang telah mereka saksikan.

Aktivitas guru pada bagian inti pembelajaran sudah sangat baik. guru menggunakan strategi dan metode yang tepat dalam pembelajaran. Pembentukan kelompok yang berjumlah 5 orang, sudah baik untuk mengurangi kegaduhan dalam pembelajaran. Guru pun lebih mudah memantau kemajuan belajar siswa. Dalam belajar kelompok, siswa tidak hanya sekadar menghafal cerita, namun siswa ditugaskan menyusun kartu skenario berdasarkan alur cerita (bagian awal cerita, bagian tengah cerita, dan bagian akhir cerita). Hal ini dimaksudkan agar siswa lebih memahami dan dapat mengingat cerita dengan baik.

Pada pertemuan kedua, tindakan juga diberikan kepada siswa namun dalam kelompok kecil yang beranggotakan 2 orang. Siswa bekerja dengan teman sebangku. Siswa merasa senang dan leluasa menggunakan kartu skenario. Pembentukan kelompok seperti ini sangat memungkinkan untuk kelancaran proses pembelajaran. Suasana kelas menjadi kondusif, aman, dan terkendali.

Bagian akhir kegiatan pembelajaran (penutup) dilakukan guru dengan baik. Secara keseluruhan, aktivitas guru pada siklus kedua ini sudah mengalami peningkatan yang cukup tinggi, dengan kategori sangat baik.

Pada pertemuan ketiga dalam siklus 2 ini, pembelajaran dibuka oleh guru dengan bertanya jawab dengan siswa mengenai kegiatan bercerita yang sudah dipelajari sebelumnya. Selanjutnya guru menyampaikan aspek-aspek yang dinilai dalam penilaian kemampuan bercerita. Pada pertemuan ketiga ini, tindakan tidak diberikan lagi, karena siswa harus mempersiapkan diri untuk melakukan penilaian 
kemampuan bercerita secara individu. Guru melakukan penilaian sesuai dengan rubric yang telah dipersiapkan.

Berdasarkan deskripsi tersebut, secara umum aktivitas guru dalam proses pembelajaran pada siklus 2 ini sudah sangat baik, baik dari kegiatan awal, kegiatan inti, maupun dalam kegiatan akhir (penutup). Perolehan skor ratarata aktivitas guru dalam proses pembelajaran bercerita adalah 86,00 dengan kategori sangat baik, sesuai dengan yang diharapkan dalam penelitian ini.

\section{Aktivitas Siswa dalam Proses Pembelajaran}

Aktivitas siswa dalam proses pembelajaran bercerita sudah sangat baik sesuai dengan yang diharapkan. Pada awal pertemuan, siswa sudah memperlihatkan minat yang tinggi ketika mengikuti pembelajaran. Hampir tidak ada siswa yang mengalihkan perhatiannya kepada hal lain, kecuali hanya pada pembelajaran yang sedang berlangsung. Dengan antuasias mereka meminta guru untuk menayangkan lagi video bercerita, karena mereka melihat guru membawa in fokus. Ketika tayangan video ditampilkan, mereka kelihatan sangat konsentrasi dan memusatkan perhatian terhadap cerita yang sedang diperlihatkan.

Siswa juga sangat aktif ketika bekerja dalam kelompok. Tugas yang diberikan oleh guru mereka kerjakan dengan kompak dan bersemangat. Mereka secara bergiliran dan mengambil bagian dalam memerankan watak tokoh cerita, membaca skenario cerita dengan lafal dan intonasi yang keras. Siswa Setiap kelompok kelihatan aktif dan bekerja sama dalam pembelajaran.

Dalam kegiatan menampilkan cerita secara kelompok ke muka kelas, mereka berlomba menjadi kelompok yang terbaik. hampir semua siswa memiliki keberanian menampilkan ekspresi mereka. Meski ada beberapa siswa yang masih malu-malu untuk berekspresi, tetapi selalu diberi semangat oleh guru maupun oleh siswa lainnya. Keberanian siswa dalam bercerita secara berkelompok sudah sangat baik.

Secara umum rata-rata aktivitas siswa dalam proses pembelajaran pada siklus 2 ini sudah berada pada kategori sangat baik, yakni 83,00 . Aktivitas siswa secara individu minimal sudah berada pada kategori baik (berada pada rentang >60-80). Dengan demikian, hasil ini sudah memenuhi indikator keberhasilan dalam penelitian ini.

\section{Kemampuan Bercerita}

Kemampuan bercerita siswa pada siklus 2 ini sudah menunjukkan peningkatan yang sangat berarti dari siklus sebelumnya. Terdapat 14 (empat belas) siswa yang mampu bercerita dengan sangat baik dengan skor rata-rata $>80$, sisanya 21 (duapuluh satu) siswa mampu bercerita dengan baik dengan perolehan skor rata-rata berada pada rentang $>60-80$. Penggunaan media kartu skenario secara berulang-ulang dengan berbagai strategi dan metode dan cerita yang sama, berhasil membuat siswa lancar dalam bercerita. Pada umumnya siswa dapat memahami isi cerita dan sangat lancar dalam menceritakan kisah Timun Mas. Mereka memahami alur cerita dengan sangat baik.

Beberapa siswa sudah mampu menggunakan diksi/pilihan kata sehingga cerita menjadi menarik dan tidak kaku, namun kebanyakan siswa masih ragu-ragu menggunakan diksi karena lebih senang menggunakan kata yang ada pada cerita, alhasil kemampuan mereka dalam aspek diksi/pilihan kata baru dalam kategori baik (rata-rata 70,00). Demikian juga dalam aspek ketepatan ekspresi. Kebanyakan siswa ketika diadakan penilaian, mereka justru menjadi gugup dan malu menggunakan ekspresinya sehingga cerita menjadi kurang menarik. Kemampuan siswa pada aspek ketepatan ekspresi memperoleh rata-rata 67,00 atau berada pada kategori baik.

Kemampuan siswa pada aspek lainnya seperti kejelasan lafal dan intonasi suara, ketepatan makna seluruh cerita, dan kelancaran bercerita sudah sangat baik. Siswa sudah bisa bercerita dengan lafal yang jelas, suara yang keras, dan menggunakan intonasi suaranya, meski belum sempurna. Demikian juga dalam ketepatan makna seluruh cerita, sudah dapat disampaikan dengan sangat baik dan tepat. Siswa juga sudah lancar bercerita dari awal sampai akhir, meski masih ada beberapa siswa sedikit terbata-bata dalam menyampaikan cerita.

\section{Manajemen Kelas}

Kegiatan manajemen kelas di siklus 2 ini sudah dapat dilaksanakan guru dengan baik. Guru sudah dapat melaksanakan pembelajaran dengan baik sesuai dengan alokasi waktu yang telah ditetapkan di dalam Rencana Pelaksanaan Pembelajaran. Pembelajaran bercerita menjadi menarik dan menyenangkan bagi siswa karena guru mengajar dengan berbagai variasi, baik 
dari segi metode maupun strategi dengan menggunakan beberapa media pokok dan media penunjang. Guru sudah dapat mengatasi beberapa siswa yang biasanya pasif mengikuti kegiatan pembelajaran dengan selalu melibatkan mereka dengan memberi berbagai pertanyaan. Siswa yang pemalu dan kurang memiliki percaya diri untuk bercerita sudah dapat diatasi oleh guru dengan cara memberikan penguatan berupa pujian walaupun kemampuan berceritanya belum sempurna. Selain itu, guru menggabungkan mereka ke dalam kelompok siswa yang memiliki keberanian dan percaya diri dalam bercerita, sehingga mereka juga ikut termotivasi bercerita seperti yang dilakukan temanteman kelompoknya.

Berdasarkan hasil pengamatan, capaian keberhasilan pada siklus 1 adalah sebagai berikut (1) penggunaan media kartu skenario dalam pembelajaran bercerita sudah berhasil memperbaiki proses pembelajaran, baik dari segi aktivitas guru, maupun aktivitas siswa. Peningkatan yang terjadi sangat baik dan sudah sesuai dengan yang diharapkan. Penggunaan kartu skenario sudah efektif jika digunakan pada siswa dengan jumlah anggota kelompok yang tidak terlalu banyak, dan makin efektif jika kartu skenario digunakan pada siswa dalam kelompok kecil (berpasangan dengan teman sebangku). Siswa memiliki waktu yang penuh untuk dapat memahami dan menghafal cerita, lebih leluasa menggunakan kartu karena tidak perlu khawatir lagi harus berebut kartu dengan teman lainnya, (2) aktivitas guru dalam proses pembelajaran, sudah dapat dikatakan mengalami peningkatan yang sangat baik. Guru sudah berupaya memperbaiki segala kekurangan yang terdapat pada pembelajaran sebelumnya. Kegiatan pembelajaran yang menyangkut kegiatan awal, inti, dan penutup dilaksanakan oleh guru sesuai dengan rencana pembelajaran yang telah dibuat sebelumnya, walaupun masih terdapat beberapa kekurangan, (3) aktivitas siswa dalam proses pembelajaran sudah mengalami peningkatan yang sangat baik. Keterlibatan siswa dalam pembelajaran seperti keaktifan, perhatian dan konsentrasi, minat, dan keberanian siswa sudah mulai menampakkan hasil yang sangat baik. Hal ini perlu dipertahankan dalam pembelajaran untuk masa yang akan datang, (4) kemampuan bercerita siswa sudah mengalami peningkatan. Secara individu siswa sudah memiliki kemampuan yang baik dalam bercerita, diantaranya ada yang memiliki kemampuan yang sangat baik dalam bercerita. Dari enam aspek yang dinilai terdapat dua aspek yang masih perlu untuk ditingkatkan lagi terutama aspek ketepatan ekspresi dan aspek pilihan kata. Kedua aspek ini termasuk aspek yang sulit bagi siswa. Sementara aspek lainnya seperti ketepatan isi cerita, lafal dan intonasi suara, ketepatan makna cerita, dan kelancaran bercerita sudah sangat baik, untuk itu perlu dipertahankan dan (5) manajemen kelas sudah dapat dikatakan berhasil. Pembelajaran berjalan dengan lancar. Guru sudah mampu memanajemen kelasnya dengan baik, baik dari segi strategi dan variasi mengajar, memberikan motivasi bagi siswa yang pasif dan tidak memiliki keberanian dalam bercerita, maupun dari segi pengelolaan waktu pembelajaran. Walaupun dalam pengelolaan waktu masih terdapat beberapa kekurangan, namun dapat diatasi. Memang harus diakui, waktu sering menjadi kendala dalam setiap pembelajaran. Apalagi dalam pembelajaran bercerita, sangat membutuhkan waktu yang penuh agar kemampuan bercerita dapat ditingkatkan.

\section{Pembahasan}

Rangkaian siklus dalam penelitian tindakan ini telah usai. Beberapa penemuan dan hasil penting dari pelaksanaan tindakan ini akan dibahas dalam bagian ini. Berikut pembahasan yang akan disampaikan sesuai aspek yang diamati dalam peneltian ini.

\section{Penggunaan Media Kartu Skenario}

Pada awalnya siswa masih sulit menggunakan kartu skenario karena jumlahnya cukup banyak, dimana siswa harus menyusun 14 pasang kartu sehingga menjadi sebuah cerita yang urut. Selain itu, siswa juga kesulitan untuk menguasai cerita pada masing-masing kartu skenario, siswa kurang leluasa menggunakan kartu skenario karena penggunaannya secara bersama di dalam kelompok. Setelah berlalu satu siklus, barulah siswa memahami dan mengerti sepenuhnya manfaat dan cara menggunakannya. Sampai pada akhir penelitian, siswa makin baik dalam menggunakan kartu skenario sebagai cara untuk meningkatkan kemampuan bercerita siswa sekaligus dapat meningkatkan aktivitas siswa dan guru dalam proses pembelajaran.

Keefektifan penggunaan media kartu skenario dalam pembelajaran bercerita dibantu oleh adanya kolaborasi antara guru dan peneliti untuk merancang RPP secara terstruktur dengan memperbaiki strategi dan metode yang 
dilakukan oleh guru pada siklus kedua. Kelemahan-kelemahan pembelajaran yang muncul pada siklus satu, diupayakan oleh guru tidak muncul lagi pada siklus kedua.

Bahan atau materi pembelajaran yang diajarkan pada siklus kedua masih sama dengan siklus pertama. Kartu skenario cerita Timun Mas tetap diberikan kepada siswa pada siklus kedua ini. Guru sengaja tidak menggantinya, karena cerita tersebut belum sepenuhnya dikuasai oleh siswa, sehingga perlu pemantapan sampai semua siswa menguasainya. Meskipun ceritanya tidak berubah, siswa tetap bersemangat mengikuti pembelajaran, karena guru menggunakan strategi dan metode yang bervariasi dalam penggunaan media yang digunakan.

Penggunaan media kartu skenario bukan hanya sekedar dapat menarik perhatian dan menimbulkan motivasi belajar bagi siswa, lebih dari itu, media kartu skenario mampu mengembangkan kemampuan siswa dalam ranah kognitif, afektif dan psikomotorik. Selain mengasah keterampilan berbicara, pembelajaran bercerita dengan menggunakan kartu skenario dapat mengasah kemampuan membaca dan menyimak. Tindakan yang dilakukan dalam penelitian tindakan ini mengalami perubahan dan perbaikan demi mengarah pada hasil yang diharapkan, yakni adanya perbaikan kondisi belajar yang dipengaruhi oleh cara mengajar guru, baik dari strategi, metode, maupun media pembelajaran. Proses pembelajaran bahasa Indonesia dalam aspek berbicara khususnya bercerita, menjadi lebih menarik dan menyenangkan.

\section{Aktivitas Guru dalam Proses Pembelajaran}

Aktivitas guru dalam proses pembelajaran sudah mengalami peningkatan dalam penelitian ini. Aktivitas guru yang diamati berdasarkan pada langkah-langkah pelaksanaan pembelajaran yang tertuang dalam RPP. Secara garis besar, langkah-langkah tersebut dibagi atas tiga kelompok, yakni kegiatan awal, kegiatan inti, dan kegiatan akhir (penutup).

Secara keseluruhan, aktivitas guru dalam proses pembelajaran bercerita sudah mengalami peningkatan dari kategori baik di siklus pertama menjadi sangat baik di siklus kedua. Peningkatan aktivitas guru pada masing-masing kegiatan dapat dilihat secara visual pada grafik berikut.

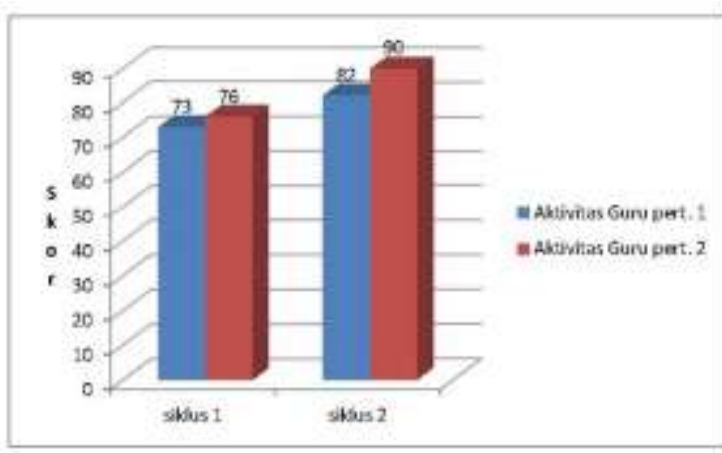

Gambar 1. Peningkatan Aktivitas Guru Tiap Pertemuan dalam 2 Siklus

Peningkatan aktivitas guru dalam proses pembelajaran sebesar 11,00 poin. Pada siklus satu rata-rata aktivitas guru sebesar 75,00 dan terjadi peningkatan di siklus 2 dengan ratarata aktivitas guru sebesar 86,00. Untuk lebih jelasnya peningkatan aktivitas guru dalam proses pembelajaran ditampilkan dalam grafik sebagai berikut.

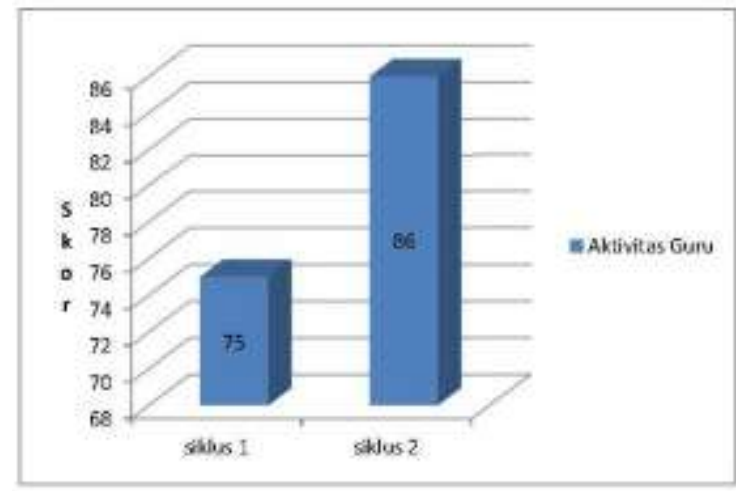

Gambar 2. Peningkatan Aktivitas Guru dalam Proses Pembelajaran

\section{Aktivitas Siswa Dalam Proses Pembelajaran}

Peningkatan yang terjadi pada aktivitas siswa dalam pembelajaran bercerita menggunakan media kartu skenario dipengaruhi oleh beberapa hal. Beberapa hal yang berpengaruh terhadap peningkatan aktivitas siswa tersebut adalah peranan guru dan siswa dalam pembelajaran, alat pendukung, materi atau bahan ajar, dan strategi pembelajaran yang digunakan. Peranan guru dalam pembelajaran yang mendukung meningkatnya aktivitas siswa adalah penciptaan kesempatan pada siswa untuk berinteraksi dengan teman lain dalam belajar kelompok, sikap guru yang perhatian secara merata dan memotivasi siswa untuk memiliki keberanian, dan pemberian stimuli dalam mengajar terhadap semua siswa. Dari siswa sendiri, aktivitas akan muncul apabila ada dorongan, baik berupa tunjukan atau suruhan guru maupun hal lain. 
Hal lain itu misalnya yang berasal dari teman lainnya. Siswa akan aktif apabila melihat teman lain aktif, siswa akan berani apabila teman lain juga berani. Selain itu, siswa sangat antusias untuk mendapat nilai sehingga tingkat aktivitasnya menjadi meningkat.

Peningkatan terhadap aktivitas siswa dalam tiap pertemuan pada setiap siklusnya, dengan jumlah peningkatan sebesar 10.86 poin. Untuk lebih jelasnya peningkatan aktivitas siswa dalam proses pembelajaran ditampilkan dalam grafik sebagai berikut.

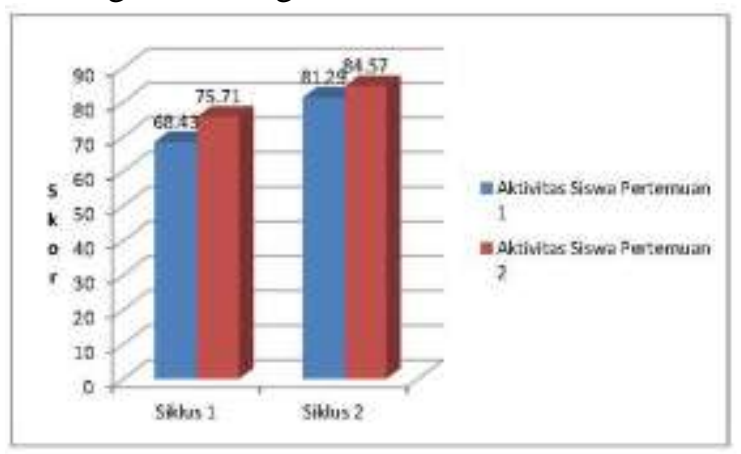

Gambar 3. Peningkatan Aktivitas Siswa Tiap Pertemuan dalam 2 Siklus

Peningkatan aktivitas siswa dalam proses pembelajaran sebesar 10,86 poin, pada siklus 1 diperoleh rata-rata skor 72,07 dan siklus 2 diperoleh 82,93 . Untuk lebih jelasnya peningkatan aktivitas siswa dalam proses pembelajaran ditampilkan dalam grafik sebagai berikut.

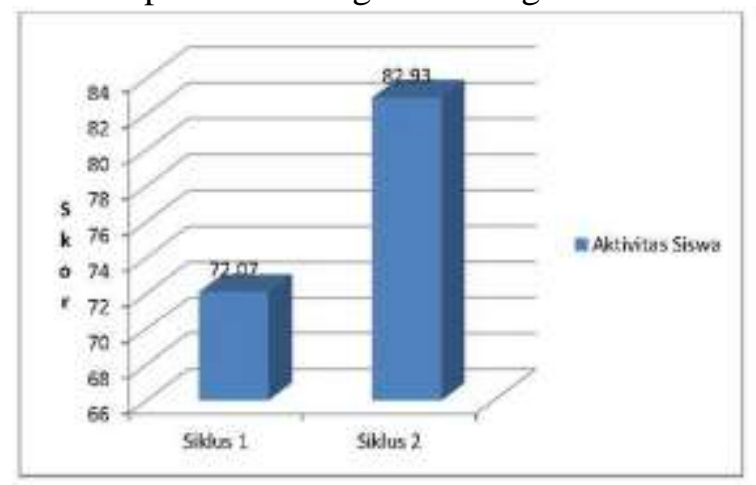

Gambar 4. Peningkatan Aktivitas Siswa dalam dua Siklus

Selain peningkatan aktivitas siswa dalam pembelajaran, berikut juga ditampilkan peningkatan yang terjadi pada masing-masing aspek aktivitas siswa dalam pembelajaran bercerita yang menyangkut aktifitas, perhatian dan konsentrasi, minat, dan keberanian siswa dalam bercerita. Peningkatan yang terjadi ditampilkan secara visual sebagai berikut.

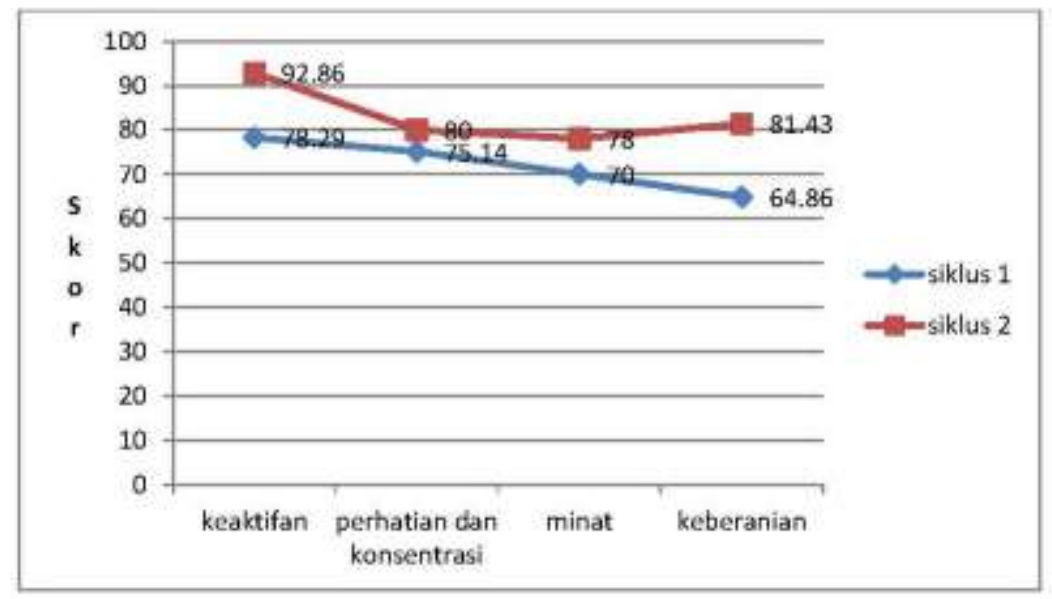

Gambar 5. Peningkatan Masing-masing aspek Aktivitas Siswa

\section{Kemampuan Bercerita Siswa}

Kemampuan siswa dalam bercerita dapat ditingkatkan melalui penggunaan media kartu skenario. Berdasarkan rata-rata hasil tes praktik bercerita yang dilaksanakan pada akhir siklus 1, kemampuan bercerita siswa memperoleh rata-rata 70,86 yang berada pada kategori baik. Meski sudah berada pada kategori baik, namun belum memenuhi kriteria keberhasilan dalam penelitian ini, yakni $\geq 75,00$. Sementara itu, prosentase ketuntasan baru mencapai $40 \%$, artinya dari 35 siswa hanya 13 orang yang memperoleh nilai $\geq 75,00$ (lihat lampiran 3a halaman 187). Pada siklus 1 kebanyakan siswa masih belum mampu menggunakan diksi/pilihan kata dalam bercerita, siswa masih terpaku pada kata-kata yang ada pada cerita. Siswa masih ragu-ragu dan malu-malu menggunakan ekspresi seperti mimik muka dan gerak-gerik. 
Peningkatan kemampuan bercerita siswa pada siklus ke-2 sudah menunjukkan hasil yang memuaskan. Perolehan skor rata-rata siswa sebesar 80,00 dan ketuntasan klassikal sebesar $77 \%$ atau siswa yang tuntas sebanyak 27 orang dari 35 siswa. Siswa sudah menunjukkan dan meningkatkan kemampuan mereka dalam bercerita. Kemampuan dalam menyampaikan alur cerita, tokoh, serta unsur-unsur cerita sudah sangat baik. Seringnya siswa berlatih mengulang cerita dengan menggunakan kartu skenario baik secara kelompok maupun secara individu menjadikan mereka lancar dalam bercerita. Adanya contoh peragaan bercerita melalui tayangan video dan contoh bercerita oleh salah seorang teman di muka kelas, memacu siswa lain untuk dapat berbuat seperti orang lain.

Aspek kemampuan bercerita yang masih agak sulit untuk ditingkatkan adalah ketepatan ekspresi dan ketepatan pilihan kata. Kedua aspek untuk siswa sekolah dasar terutama di kelas III masih jarang dilakukan, sehingga penghayatan dan pemahaman terhadap cerita belum sempurna dan tingkat perbendaharaan kata (kosa kata) masih sedikit. Kebanyakan siswa masih kurang mampu untuk menggunakan ekspresi terutama yang menyangkut mimik muka dan pemahaman terhadap ungkapan-ungkapan atau istilah dalam cerita.

Adanya variasi dalam mengajar yang dilakukan guru, misalnya variasi suara, kontak badan dan mimik, pemahaman terhadap siswa, memberikan penguatan yang positif, memberikan peluang kepada siswa untuk berinteraksi dengan teman, dapat membantu siswa untuk meningkatkan kemampuan dalam berekspresi maupun penggunaan kata. Melalui kemampuan berekspresi dan kemampuan menggunakan diksi, siswa dapat meningkatkan perkembangan emosi, motorik, dan perkembangan kognisinya.

Kemampuan bercerita siswa makin lama makin meningkat. Pada awalnya, siswa masih belum optimal dalam melakukan kegiatan bercerita, selanjutnya siswa sudah memiliki keberanian dan percaya diri untuk bercerita. Semua aspek kemampuan bercerita seperti ketepatan isi cerita, lafal dan intonasi suara, makna cerita, kelancaran bercerita, pilihan kata dan ekspresi sudah dapat meningkat. Peningkatan kemampuan siswa di dalam bercerita dapat diketahui dari kuantitas siswa yang semakin banyak siswa yang dapat memenuhi kriteria ketuntasan kemampuan bercerita pada tiap-tiap aspek.

Perolehan rata-rata kemampuan bercerita siswa belum tuntas pada siklus pertama, dan di siklus kedua sudah tuntas dengan peningkatan sebesar 9,14 poin. Secara visual akan ditampilkan peningkatan yang terjadi pada tiap siklus.

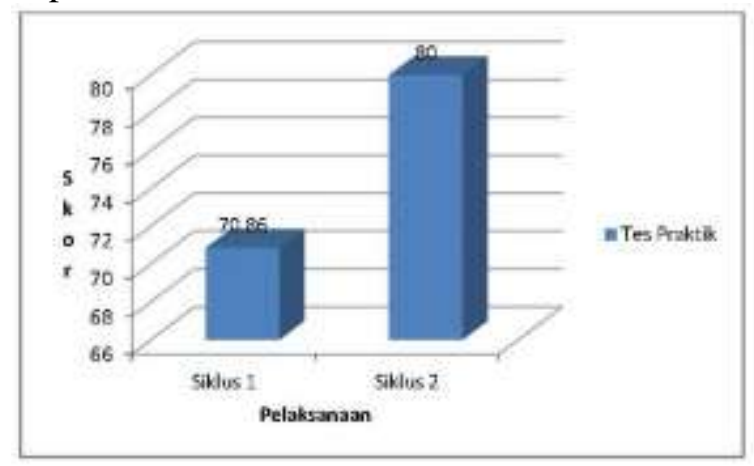

Gambar 6. Peningkatan Kemampuan Bercerita Siswa

Selain peningkatan kemampuan ratarata siswa, peningkatan yang terjadi pada masing-masing aspek kemampuan bercerita juga dapat digambarkan sebagai berikut.

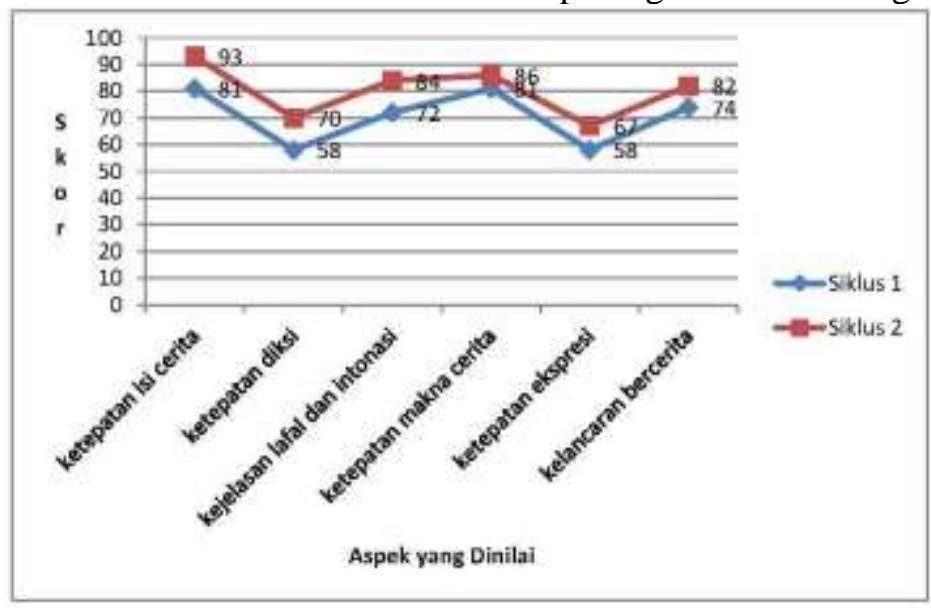

Gambar 7. Peningkatan Masing-masing Aspek Kemampuan Bercerita 
Masing-masing aspek kemampuan bercerita mengalami peningkatan dengan peningkatan sebesar 9,14 poin. Pada gambar di atas, sudah terlihat bahwa masing-masing aspek kemampuan bercerita sudah mengalami peningkatan yang cukup baik pada tiap siklusnya.

\section{Manajemen Kelas}

Guru telah berhasil menciptakan dan memelihara kondisi belajar yang optimal bagi siswa. Beberapa gangguan dalam pembelajaran, seperti adanya perselisihan antara siswa yang terjadi di dalam kelompok ketika belajar kelompok, sudah dapat diatasi oleh guru dengan baik. Selain itu, variasi mengajar yang dilakukan oleh guru juga sudah mampu menimbulkan suasana yang hangat dan menyenangkan bagi siswa. Guru juga telah dapat mengelola waktu pembelajaran dengan baik, meskipun belum optimal. Masalah waktu memang selalu menjadi kendala dalam setiap pembelajaran, tidak terkecuali dalam pembelajaran bercerita. Siswa membutuhkan waktu yang cukup banyak untuk dapat membaca cerita, memahami, menghafal, dan menampilkannya dengan optimal.

Berdasarkan penelitian yang dilakukan di atas, peneliti dapat memperoleh beberapa pengetahuan yang berhubungan dengan penggunaan media kartu skenario sebagai salah satu media yang efektif dalam pembelajaran.

Beberapa pengetahuan yang diperoleh antara lain adalah: (1) Penggunaan media kartu skenario dalam pembelajaran dapat meningkatkan kemampuan bercerita yang masih rendah; (2) Penggunaan media kartu skenario dalam pembelajaran bercerita dapat meningkatkan proses pembelajaran, baik aktivitas guru, maupun aktivitas siswa; (3) Membuktikan bahwa penggunaan media kartu skenario cocok digunakan pada siswa sekolah dasar kelas III karena dapat melibatkan peserta didik secara aktif dalam pembelajaran; (4) Penggunaan media kartu skenario dalam kelompok lebih efektif dilakukan untuk menjalin kerja sama dan memotivasi keberanian siswa untuk bercerita.

\section{Simpulan dan Saran}

Simpulan

Hasil penelitian menunjukkan bahwa penggunaan media kartu skenario dalam pembelajaran bercerita terbukti berpengaruh terhadap peningkatan kemampuan dan proses pembelajaran bercerita siswa. Kemampuan bercerita peserta didik mengalami peningkatan, yaitu dari rata-rata 70,86 pada siklus 1 menjadi 80,00 pada siklus 2 dengan klasifikasi baik. Ketuntasan belajar klasikal dari $40 \%$ di siklus 1 meningkat menjadi $77 \%$ di siklus 2. Aktivitas guru dalam proses pembelajaran menunjukkan ratarata 75,00 diklasifikasikan baik pada siklus 1 menjadi 86,00 pada siklus 2 dengan klasifikasi sangat baik. Aktivitas siswa dalam proses pembelajaran dari rata-rata 72,07 pada siklus 1 menjadi 82,93 pada siklus 2 dengan klasifikasi sangat baik. Jadi pelaksanaan tindakan menggunakan media kartu skenario telah mencapai indikator keberhasilan dalam penelitian ini, yakni nilai perolehan rata-rata kemampuan bercerita $\geq 75,00$ dan ketuntasan belajar klasikal mencapai $75 \%$. Pelaksanaan proses pembelajaran baik dari aktivitas guru maupun aktivitas siswa memperoleh rata-rata $>80,00$ dengan klasifikasi sangat baik. Dengan demikian penggunaan media kartu skenario dapat meningkatkan kemampuan bercerita dan dapat meningkatkan proses pembelajaran bercerita siswa kelas III di SD Negeri 08 VI Suku, Solok.

\section{Saran}

Telah terbuktinya peningkatan kemampuan bercerita dan meningkatnya proses pembelajaran bercerita dengan menggunakan media kartu skenario, maka peneliti menyarankan halhal sebagai berikut.

Kepada guru, khususnya guru kelas di SD Negeri 08 VI Suku Kota Solok, agar lebih memahami dan merancang pembelajaran berbicara khususnya bercerita dengan menggunakan media kartu skenario agar lebih inovatif, dan berusaha mengimplementasikan-nya dalam pembelajaran bercerita di kelas.

Kepada peneliti selanjutnya: (a) Pada penelitian ini penelitian ditujukan untuk meningkatkan kemampuan bercerita dan meningkatkan proses pembelajaran yang menyangkut aktivitas guru dan siswa dengan menggunkan media kartu skenario. Bagi calon peneliti lainnya mungkin dapat melakukan tinjauan lain seperti meningkatkan kreativitas siswa, minat belajar, motivasi, maupun prestasi belajar; (b) Penelitian ini dilakukan pada standar kompetensi memahami teks dengan membaca nyaring, membaca intensif, dan membaca dongeng dengan kompetensi dasar menceritakan isi dongeng yang dibaca. Kemungkinan untuk diujicobakan pada standar kompetensi lain dapat dilakukan dengan mempertimbangkan kesesuaiannya. 


\section{Daftar Pustaka}

Blair, C. (2013). Using flashcard to remember information. Diambil pada tanggal 13 Juni 2013, dari http://www.how-tostudy.com/study-skill/en/32.asp

Donoghue, M. R. (2009). Language arts: Integrating skill for classroom teaching. California: Sage Publication, Inc.

Hopkins, D. (2011). Panduan guru: Penelitian tindakan kelas. (Terjemahan Achmad Fawaid). New York: McGraw HillOpen University Press. (Buku asli diterbitkan tahun 2008)

Kemendiknas. (2006). Peraturan Menteri Pendidikan Nasional Nomor 22, tahun 2006, tentang Standar Isi.

Kemmis, S \& Taggart, R. (1990). The action research planner. Victoria: Deakin University Press.

Nurgiyantoro, B. (2012). Penilaian pembelajaran bahasa berbasis kompetensi. Yogyakarta: BPFE
Nurseto, T. (2011). Membuat media pembelajaran. Jurnal Ekonomi dan Pendidikan, 8 (1), 19-35.

Richard-Amato, P. A. (2003). Making it happen: from interactive to participatory language teaching. New York: Pearson Education.

Schunk, D. (2008). Learning theories an educational perspective. New Jersey: Pearson Prentice Hall.

Tarigan, H. G. (2008). Berbicara sebagai suatu keterampilan berbahasa. Bandung: Angkasa

Tompkins, G. E \& Hoskisson, K. (1995). Language arts: Content and teaching strategies. New Jersey: Prentice-Hall, Inc.

Trianto. (2007). Model-model pembelajaran inovatif berorientasi konstruktivitik. Jakarta: Prestasi Pustaka. 